\title{
BENTUK DAN MAKNA UNGKAPAN PANTANG LARANG KOMUNITAS ADAT DESA KARANG PANDAN KECAMATAN PAKISAJI KABUPATEN MALANG DALAM SEBUAH PENAFSIRAN HERMENUTIKA BUDAYA
}

\author{
Eka Ratmawati \\ (eka.ratmawati206@gmail.com) \\ Universitas Kanjuruhan Malang
}

\begin{abstract}
Abstrak
Masyarakat merupakan kumpulan beberapa individu yang mempunyai latar belakang dan ciri khas tersendiri sesuai dengan lingkungan yang di tempatinya, kemudian membentuk suatu kebudayaan. Kebudayaan yang ada itu merupakan cerminan dari kehidupan masyarakat, baik dari segi mata pencaharian, religi, ilmu pengetahuan juga kebudayaan yang terbentuk dari kepercayaan rakyat. Kepercayaan yang diwariskan secara turun temurun dari generasi ke generasi berikutnya, baik secara tulis maupun lisan disebut folklor. Seperti halnya pantang larang/ mitos adalah cerita yang memuat kepercayaan orang Jawa terhadap hal-hal yang sakral. Pantang larang/ mitos tergolong genre tradisi lisan, pada dasarnya tak jauh berbeda dengan tradisi Jawa tulis. Pantang larang atau pamali merupakan makna larangan yang diungkapkan oleh orang-orang terdahulu dalam kondisi masyarakat yang masih mistis. Ungkapan lisan berpola yang hadir secara turun-temurun itu sering di dengar dari para orang tua, misalnya kakek atau nenek masing-masing.
\end{abstract}

Kata-kata Kunci: pantang larang, bentuk, makna

\begin{abstract}
Society is bunch of individuals that have the same backgrounds and characteristics based on their environments, then make a culture. The culture is reflection of the society's life such as job, religion, knowledge and culture that is formed by people's belief. Belief that is passed down from generation to generation written or verbally is called folklore. Such as Javanese myth, is story that tells about Javanese's belief to sacred things. Myth is one of oral traditions, basically not too different with Javanese's written tradition. Myth or pamali means warning that ancient people used. The warning that comes from generation to generation is often heard from the old people, such as grandpas and grandmas.
\end{abstract}

Keywords: myth, form, mean

Pada awalnya, istilah tradisi lisan merupakan ciri peradaban primitif. Tradisi merupakan bentuk warisan panjang. Lisan adalah bentuk pewarisan yang khas. Tradisi lisan, adalah warisan leluhur Jawa yang abadi. Sebuah mutiara kultur leluhur yang hampir terlupakan oleh banyak orang, namun tetap bertahan. Tradisi itu ada, lestari, hidup, berkembang, tanpa paksaan dan tekanan (Endraswara, 2005: 1). Jika dicermati, ternyata tradisi lisan itu juga berkaitan dengan folklor dan tradisi. Kelisanan memang menjadi ciri khas folklor, tradisi, tradisi lisan. Cakupan folklor memang lebih luas dibanding tradisi lisan. Tradisi lisan adalah karya folklore yang bernuansa tradisi (Endraswara, 2005: 10). Folk artinya rakyat dan lore artinya tradisi (tradisi). Folk adalah kelompokatau kolektif yang memiliki ciri-ciri pengenal kebudayaan yang membedakan dengan kelompok lain. Lore merupakan wujud tradisi dari folk. Tradisi tersebut diturunkan secara oral (lisan) dan turun temurun. Folklor berarti tradisi rakyat. Batasan ini menujukkan bahwa folkor adalah bagian budaya yang sering disampaikan secara 
lisan. Ternyata aspek folklor yang penting terletak pada sifat ketradisionalan dan kelisanan. Jadi folklor merupakan wujud budaya yang lebih luas baik lisan maupun non lisan. Dalam budaya tersebut ada yang dinamakan tradisi dan tradisi lisan. Dapat dinyatakan bahwa tradisi lisan lebih menitikberatkan aspek estetika, tradisi menitikberatkan pada aspek-aspek keberulangan dan pewarisan. Sedangkan budaya cenderung menekankan aspek tradisi yang lebih luas. Dengan demikian folklor, tradisi dan, tradisi lisan sulit dipisahkan, ketiganya saling melengkapi. Folklor akan membuat tradisi lisan semakin dipercaya oleh kolektifnya. Tradisi dan tradisi lisan akan memperkaya folklor itu sendiri (Endraswara, 2005: 11).

Pantang larang atau lebih dikenal dengan pamali atau mitos adalah cerita yang memuat kepercayaan orang Jawa terhadap hal-hal yang sakral. Pantang larang/ mitos tergolong genre tradisi lisan, pada dasarnya tak jauh berbeda dengan tradisi Jawa tulis (Endraswara, 2005: 12). Menurut Sarmidi (2014: 1-2) pantang larang atau pamali merupakan makna larangan yang diungkapkan oleh orang-orang terdahulu dalam kondisi masyarakat yang masih mistis. Ungkapan lisan berpola yang hadir secara turuntemurun itu sering di dengar dari para orang tua, misalnya kakek atau nenek masingmasing. Bisa ditafsirkan pantangan-pantangan atau larangan-larangan disampaikan oleh para generasi pendahulu menjadi suatu kata-kata bijak yang berisi kearifan lokal. Tentu saja, ungkapan-ungkapan dalam wujud kata-kata atau kalimat berpola yang berisi pantangan atau larangan itu berawal dari sejumlah kasus baik yang terselesaikan karena dapat dinalar keberadaannya maupun yang cukup diterima karena dipercaya begitu saja, diturunkan antargenerasi dalam beberapa situasi tanpa penalaran yang jelas. Segala sesuatu terjadi karena kehendak Tuhan. Tetapi, sebagai sebuah ungkapan yang didasarkan pada mitos, legenda, atau peristiwa-peristiwa yang dianggap ganjil sebagaimana disebutkan sebagai ungkapan pantang larang atau pamali merupakan fenomena bahasa bahkan disikapi sebagai genre sastra lisan di Indonesia. Begitulah uniknya tradisi lisan negeri ini, misalnya pantang larang untuk anak-anak tidak boleh makan berpindah-pindah tempat nanti akan mendapatkan ibu tiri, tidak boleh tidur berselimut tikar nanti akan digulung ombak, tidak boleh berteriak-teriak dalam hutan khawatir dimasuki roh halus atau akan kesurupan.

Dalam penelitian ini akan diuraikan penelitian ungkapan pantang larang yang sering dituturkan oleh komunitas adat Desakarang Pandan. Pantang larang yang sering dituturkan oleh komunitas adat Desa Karang Pandan sebagai berikut: (1) Wong meteng ora oleh mangan karo turu, mergo lek ngelairno bolak-balik turu. Jika diartika ke dalam bahasa Indonesi orang hamil tidak boleh makan sambil tidur, karena kelak jika melahirkan akan sering tertidur. (2) Ora oleh anil nang jero omah, mergo ngundang bekasakan (barang alus). Jika diartikan ke dalam bahasa Indonesia tidak boleh bersiul di dalam rumah,karena akan mendatangkan roh-roh halus.

Maka dari itu, penulis ingin menjadi orang pertama yang akan mengkaji tentang tulisan ini. Alasan penulis selain ingin menjadi orang pertama yang akan mengkaji tentang ungkapan pantang larang ini, penulis juga ingin mengerti tentang kebudayaan yang ada di sekitar wilayah rumah penulis yaitu Desa Karang Pandan Kecamatan Pakisaji Kabupaten Malang. Dengan latar belakang tersebut, penulis tertarik untuk 
mengkaji Bentuk dan Makna Ungkapan Pantang Larang Komunitas Adat Desa Karang Pandan Pakisaji Kabupaten Malang dalam sebuah Penafsiran Hermeneutika Budaya.

Berdasarkan latar belakang tersebut, peneliti merumuskan hal-hal yang menjadi pokok permasalahan, yaitu masalah umum dalam penelitian ini adalah bagaimana ungkapan pantang larang dalam komunitas adat Pakisaji. Sedangkan rumusan masalah secara khusus dalam penelitian ini dirumuskan sebagai berikut: (1) Bagaimanakah bentuk ungkapan pantang larang dalam komunitas adat Desa Karang Pandan Kecamatan Pakisaji? (2) Bagaimanakah makna ungkapan pantang larang dalam komunitas adat DesaKarang Pandan Pakisaji?

Dilihat dari tinjauan rumusan masalah, peneliti juga merumuskan tujuan ungkapan pantang larang komunitas dalam adat Desa karang Pandan Kecamatan Pakisaji. Secara umum tujuan dalam penelitian ini adalah mendeskripsikan ungkapan pantang larang dalam komunitas adat Desa Karang Pandan Pakisaji. Sedangkan secara khusus tujuan penelitian ini ungkapan pantang larang dalam komunitas adat Desa Karang Pandan Kecamatan Pakisaji sebagai berikut: (1) Mendeskripsikan bentuk ungkapan pantang larang dalam komunitas adat Desa Karang Pandan Kecamatan Pakisaji? (2) Mendeskripsikan makna ungkapan pantang larang dalam komunitas adat Desa Karang Pandan Kecamatan Pakisaji?

Manfaat teoretis dalam penelitian ungkapan pantang larang dalam komunitas adat Desa Karang Pandan Kecamatan Pakisaji sebagai berikut: (1) Penelitian ini diharapkan bermanfaat sebagai salah satu rujukan untuk merangsang penelitian sastra Indonesia. Penelitian ini diharapkan dapat membantu penelitian selanjutnya yang berhubungan dengan ungkapan pantang larang dalam komunitas adat, (2) Sebagai salah satu sumbangan untuk menambah pengetahuan tentang perkembangan sastra Indonesia. (3) Penelitian ini juga diharapkan bermanfaat bagi penelitian-penelitian berikutnya. Baik penelitian ungkapan pantang larang dalam komunitas adat maupun penelitian karya sastra lainnya.

Manfaat praktis dalam penelitian ini bagi komunitas adat yaitu: (1) Membantu komunitas adat untuk memahami nilai budaya, mitos, dan filsafat Jawa. (2) Menumbuhkan semangat komunitas adat untuk mencintai dan melestarikan kebudayaan daerah masing-masing. (2) Memperkaya pengetahuan kesusastraan Indonesia. Sedangkan manfaat bagi peneliti adalah sebagai langkah awal dalam proses penyusunan skripsi. Serta untuk melatih dalam mempersiapkan diri menjadi peneliti atau menjadi guru Bahasa dan Sastra Indonesia yang mampu menguasai tentang berbagai teori dalam pembahasan karya sastra baik sastra lisan maupun sastra tulis.

\section{FOLKLOR}

Foklor berasal dari kata bahasa Inggris folklore. Kata itu adalah kata majemuk yang berasal dari dua kata dasar yaitu folk dan lore. Folk yang sama artinya dengan kata kolektif (collectivity). Menurut Dundes, folk adalah sekelompok orang yang memilki ciri-ciri pengenal fisik, sosial, dan kebudayaan, sehingga dapat dibedakan dari kelompok-kelompok lainnya. Namun yang lebih penting lagi adalah bahwa mereka telah memiliki suatu tradisi, yaitu kebudayaan yang telah mereka warisi turun-temurun, 
sedikitnya dua generasi yang dapat mereka akui sebagai milik bersamanya. Di samping itu, yang paling penting adalah bahwa mereka sadar akan identitas kelompok mereka sendiri (Dundes, 1965: 2; 1977: 17-35; 1978: 7).

Jadi, folk adalah sinonim pengenal fisik atau kebudayaan yang sama serta mempunyai kesadaran kepribadian sebagai kesatuan masyarakat. Sedangkan lore adalah tradisi folk, yaitu sebagian kebudayaannya yang diwariskan secara turun temurun secara lisan atau melalui suatu contoh yang disertai dengan gerak isyarat atau alat pembantu pengingat (mnemonic device). Definisi folklore secara keseluruhan adalah sebagian kebudayaan suatu kolektif, yang tersebar dan diwariskan secara turun-temurun, di antara kolektif macam apa saja, ecara tradisional dalam versi yang berbeda, baik dalam bentuk lisan maupun contoh yang disertai dengan gerak isyarat atau alat pembantu pengingat (mnemonic device) (Rafiek, 2012: 50-51). Folklor merupakan sebagian kebudayaan suatu kolektif yang tersebar dan diwariskan turun temurun di antara kolektif macam apa saja secara tradisional dalam versi yang berbeda, baik dalam bentuk lisan maupun corak disertai dengan gerak isyarat atau alat pembantu pengingat (mnemonic devices) (Danandjaja, 1982: 3). Menurut Bruvand (dalam Hutomo, 1991: 8) membedakan folklor menjadi tiga macam, yaitu: (1) folklor lisan (verbal folklore), (2) folklor setengah lisan (party verbal folklore), dan (3) folklor bukan lisan (nonverbal folklore). Secara praktis ketiganya dapat dikenali melalui bentuk masing-masing, yaitu: oral (mentifact), sosial (socifact), dan material (artifact). Folklor lisan terdiri atas: a) ungkapan tradisional (pepatah, peribahasa, semboyan), b) nyanyian rakyat (nyanyian untuk menidurkan anak seperti nina bobok, bibi anu), c) bahasa rakyat (dialek, julukan sindiran, bahasa rahasia, bahasa remaja, dan sebagainya), d) teka-teki (berbagai bentuk tanya jawab pada umumnya untukmengasah pikiran), e) cerita rakyat (mite, legende, sage). Folklor setengah lisan, diantaranya: a) drama rakyat (ketoprak, ludruk, wayang kulit, legendria, arja), b) tari (serimp, maengket, pendet), c) upacara (kelahiran, perkawinan, kematian), d) permainan dan hiburan rakyat (sembunyi-sembunyian, teka-teki), e) adat kebiasaan (gotong royong, menjenguk orang mati), f) pesta rakyat (sekaten, pesta kesenian Bali). Folklor nonlisan, di antaranya: a) material (mainan, makanan, arsitektur, alat-alat musik, pakaian, perhiasan, obat-obatan, dan sebagainya, b) bukan material (bunyi musik, bunyi gamelan, bahasa isyarat). Jadi, folklor meliputi ketiga bidang tersebut. Folklor lisan dalam hubungan ini disamakan dengan sastra lisan, sedangkan folklor setengah lisan dan nonlisan termasuk tradisi lisan.

Tradisi lisan adalah sebuah wadah budaya lisan yang mampu menampung segala aspek warisan kolektif. Namun demikian, ada sebagian orang yang memandang tradisi lisan lebih keren serta mewadahi aspirasi, sedangkan folklor sering dikonotasikan sebagai hal yang kebenarannya disangsikan. Tradisi lisan dapat ditinjau dari dua aspek, yaitu aspek proses dan produk. Sebagai produk, tradisi lisan merupakan pesan lisan yang didasarkan pada pesan generasi sebelumnya (Endraswara, 2005: 3). Tradisi lisan sebagai proses, berupa pewarisan pesan melalui mulut ke mulut sepanjang waktu hingga hilangnya pesan itu. Dengan kata lain, tradisi lisan akan terjadi apabila ada kesakisian seseorang secara lisan terhadap peristiwa. Kesaksian itu diteruskan orang lain secara lisan pula, sehingga menyebar kemana saja. Keterulangan kesaksian peristiwa inilah yang menciptakan sebuah tradisi lisan. Folklor lebih menekankan pada aspek turun temurun, kepolosan, keaslian, dan kolektif (Endraswara, 2005: 4). Genre tradisi lisan pada dasarnya tak jauh berbeda dengan tradisi Jawa tulis. Kategori besar genre tradisi lisan Jawa dapat digolongkan dalam lima, yaitu: (1) cerita, yaitu tradisi lisan yang 
berupa kisahan berbentuk prosa. Wujud cerita lisan antara lain: cerita biasa, kisah anekdot, cerita perjalanan, mitos, cerita rakyat, cerita epik, cerita babad, cerita lelembut, dongeng. (2) Puisi, adalah tradisi lisan yang berupa yang syair-syair rakyat. Syair ini meliputi beberapa bentuk, antara lain: nyanyian rakyat, parikan (pantun Jawa), tembang.

(3) Ungkapan estetis, adalah cetusan gagasan yang menggunakan kata-kata indah, ini dapat berupa: mutiara kata, peribahasa, isbat, ramalan. (4) Teka-teki kata, adalah pemakaian teka-teki yang dapat menyedot perhatian orang lain, berupa: wangsalan, sandi asma, sangkalan, cangkriman puistis. (5) Pertunjukkan rakyat, adalah bentukbentuk lakon dan pertunjukkan rakyat, meliputi: drama (guyon maton, lawak, dagelan), wayang, ketoprak, jemblung, shalawatan dan sebagainya. Berbagai genre tradisi lisan tersebut sering muncul dalam kehidupan orang Jawa (Endraswara, 2005: 12-13). Jadi folklor merupakan wujud budaya yang lebih luas baik lisan maupun non lisan. Dalam budayatersebut ada yang dinamakan tradisi dan tradisi lisan. Dapat dinyatakan bahwa tradisi lisan lebih menitikberatkan aspek estetika, tradisi menitikberatkan pada aspekaspek keberulangan dan pewarisan. Sedangkan budaya cenderung menekankan aspek tradisi yang lebih luas. Dengan demikian folklor, dan tradisi, tradisi lisan sulit dipisahkan, ketiganya saling melengkapi. Folklor akan membuat tradisi lisan semakin dipercaya oleh kolektifnya. Tradisi dan tradisi lisan akan memperkaya folklor itu sendiri (Endraswara, 2005: 11).

Tabu atau pantangan adalah suatu pelarangan sosial yang kuat terhadap kata, benda, tindakan, atau orang yang dianggap tidak diinginkan oleh suatu kelompok, budaya, atau masyarakat. Pelanggaran tabu biasanya tidak dapat diterima dan dapat dianggap menyerang. Beberapa tindakan atau kebiasaan yang bersifat tabu bahkan dapat dilarang secara hukum dan pelanggarannya dapat menyebabkan pemberian sanksi keras. Tabu dapat juga membuat malu, aib, dan perlakuan kasar dari masyarakat sekitar. Dalam setiap kelompok masyarakat, terdapat kata-kata tertentu yang dinilai tabu.katakata tersebut tidak diucapkan dalam kondisi formal dan penuh sopan santun. Ketika suatu tindakan dikatakan tabu, maka segala sesuatu yang berhubungan dengan tindakan tersebut juga dianggap tabu. Seseorang pada awalnya dilarang melakukan sesuatu, kemudian dilarang untuk berbicara mengenai apapun yang berhubungan dengan hal tersebut (MH, 2013: 213).

Pantang larang atau pamali merupakan makna larangan yang diungkapkan oleh orang-orang terdahulu dalam kondisi masyarakat yang masih mistis. Ungkapan lisan berpola yang hadir secara turun-temurun itu sering di dengar dari para orang tua, misalnya kakek atau nenek masing-masing. Bisa ditafsirkan pantangan-pantangan atau larangan-larangan disampaikan oleh para generasi pendahulu menjadi suatu katakata bijak yang berisi kearifan lokal. Tentu saja, ungkapan-ungkapan dalam wujud katakata atau kalimat berpola yang berisi pantangan atau larangan itu berawal dari sejumlah kasus baik yang terselesaikan karena dapat dinalar keberadaannya maupun yang cukup diterima karena dipercaya begitu saja, diturunkan antargenerasi dalam beberapa situasi tanpa penalaran yang jelas. Segala sesuatu terjadi karena kehendak Tuhan. Tetapi, sebagai sebuah ungkapan yang didasarkan pada mitos, legenda, atau peristiwa-peristiwa yang dianggap ganjil sebagaimana disebutkan sebagai ungkapan pantang larang atau pamali merupakan fenomena bahasa bahkan disikapi sebagai genre sastra lisan di Indonesia. Begitulah uniknya tradisi lisan negeri ini, misalnya pantang larang untuk anak-anak tidak boleh makan berpindah-pindah tempat nanti akan mendapatkan ibu tiri, tidak boleh tidur berselimut tikar nanti akan digulung ombak, tidak boleh berteriak- 
teriak dalam hutan khawatir dimasuki roh halus atau akan kesurupan. Sebagian masyarakat, ungkapan pantang larang dianggap mitos. Mitos dipercaya sebagai ajaran nenek moyang tentang apa yang tidak boleh dilakukan agar tidak tertimpa musibah (Sarmidi, 2014: 1-2).

\section{METODE}

Penelitian ini menggunakan penelitian kualitatif, dengan pendekatan etnografi, dan metode deskriptif. Data dalam penelitian ini berupa tuturan verbal yang berwujud kata-kata dan kalimat pantang larang. Data dalam penelitian ini diambil dari salah satu warga Desa Karang Pandan bernama Bapak Gimun yang berusia 68 tahun. Sumber data penelitian ini adalah ungkapan pantang larang komunitas adat Pakisaji. Baik itu bentuk pantang larang yang berupa ungkapan yang dituturkan oleh informan. Dan makna pantang larang yang berupa penjelasan yang dituturkan oleh informan. Adapun teknik pengumpulan data melalui teknik observasi, wawancara, dan dokumentasi.

\section{PEMBAHASAN}

Berdasarkan analaisis data, terdapat 35 bentuk ungkapan pantang larang komunitas adat Desa Karang Pandan Kecamatan Pakisaji. Bentuk tersebut menggambarkan bahwa ungkapan pantang larang dalam komunitas adat Desa Karang Pandan Kecamatan Pakisaji banyak menggunakan bahasa Jawa yang bersifat umum. Dengan demikian, komunitas adat Desa Karang Pandan Kecamatan Pakisaji menggunakan ungkapan pantang larang yang sama. Manfaat dari penelitian ini adalah untuk mengembangkan pengetahuan tentang bentuk ungkapan pantang larang yang berupa uturan verbal dengan menggunakan bahasa Jawa. Beberapa makna ungkapan pantang larang komunitas adat Desa Karang Pandan, misalnya pantangan untuk orang hamil, suami yang mempunyai istri hamil, bayi yang baru lahir, larangan saat makan, larangan tidur saat maghrib, larangan bangun tidur setelah matahari terbit, larangan keramas pada waktu malam hari, larangan mencuci baju pada waktu malam hari, dan sebagainya. Berikut bentuk data yang berupa ungkapan dari informan adalah sebagai berikut.

Wong meteng ora oleh mangan karo turu, mergo lek ngelairno bolak-balik turu (BPL: 01). Jika diartikn ke dalam bahasa Indonesia yaitu orang hamil tidak boleh makan sambil tidur, karena kelak jika melahirkan akan sering tertidur.

Ora oleh mangan pindah enggon (mari ndek dhuwur pindah mengisor), mergo derajate ora isomundhak. (BPL: 18). Jika diartikan ke dalam bahasa Indonesia yaitu tidak boleh makan berpindah tempat (habis di atas pindah ke bawah), karena kelak derajat-nya tidak bisa naik.

Ora oleh tangi kedhisikan srengenge, mergo gelis tuwo (rambute gampang putih lan untune gampang entek) (BPL: 27). Jika diartikan ke dalam bahasa Indonesia tidak boleh bangun tidur setelah matahari terbit, karena akan cepat tua dan rambutnya cepat beruban. 
Berdasarkan bentuk ungkapan pantang larang, terdapat 35 makna ungkapan pantang larang komunitas adat Desa Karang Pandan Kecamatan Pakisaji. Makna tersebut mejelaskan tentang bentuk ungkapan pantang larang yang diperoleh dari informan. Informan menjelaskan makna menggunakan bahasa Jawa yang ditafsirkan dan di analisis oleh peneliti menjadi bahasa Indonesia. Manfaat dari makna ungkapan pantang larang adalah memberikan pengetahuan terhadap komunitas adat dan peneliti tentang adat, kebiasaan, norma dan aturan orang Jawa yang tidak sesuai dengan kaidahkaidah yang berlaku di dalam masyarakat. Pantang larang adalah hal-hal yang sering didengar dari orang tua masing-masing individu atau kakek nenek tiap individu tersebut. Pantangan tersebut tentunya berawal dari banyaknya kasus yang terjadi karena melanggar pantangan tersebut. Meski segala sesuatunya adalah bersandarkan atas kehendak Tuhan, tetapi sebagian banyak orang sering membubuhi dengan pertanyaan "percaya atau tidak?" itu semua tergantung individu masing-masing bagaimana menyikapinya. Memang pada umumnya, pantang larang bergeser dari nilai percaya ke nilai rasional, bahkan kembali ke fungsionalitas. Beberapa makna ungkapan pantang larang komunitas adat Desa Karang Pandan, misalnya pantangan untuk orang hamil, suami yang mempunyai istri hamil, bayi yang baru lahir, larangan saat makan, larangan tidur saat maghrib, larangan bangun tidur setelah matahari terbit, larangan keramas pada waktu malam hari, larangan mencuci baju pada waktu malam hari, dan sebagainya. Berikut data makna ungkapan pantang larang yang dijelaskan oleh informan.

Wong meteng ora oleh mangan karo turu, mergo lek ngelairno bolak-balik turu. Jika diartikn ke dalambahasa Indonesia yaitu orang hamil tidak boleh makan sambil tidur, karena kelak jika melahirkan akan sering tertidur.

Makna dalam data tersebut bahwa orang yang sedang hamil tidak boleh makan sambil tidur, karena menurut orang Jawa kelak jika akan melahirkan akan sering tertidur dalam proses kelahiran bayinya. Jadi alangkah baiknya jika orang hamil makan sambil duduk dan pada tempatnya agar proses kelahirannya dapat berjalan dengan lancar (MPL: 01).

Ora oleh mangan pindah enggon (mari ndek dhuwur pindah menisor), mergo derajate ora isomundhak. (BPL: 18). Jika diartikan ke dalam bahasa Indonesia yaitu t idak boleh makan berpindah tempat (habis di atas pindah ke bawah), karena kelak derajatnya tidak bisa naik.

Makna dalam data tersebut ketika makan tidak boleh berpindah-pindah tempat dari atas ke bawah alangkah lebih baik lagi jika dari bawah pindah ke atas, karena menurut orang Jawa jika berpindah tempat dari atas ke bawah maka derajatnya tidak bisa naik. Misalnya jika dalam urusan pekerjaan jabatannya tidak bisa naik, sedangkan jika dalam urusan sekolah maka tidak naik kelas (MPL: 18).

Ora oleh tangi kedhisikan srengenge,mergo gelis tuwo (rambute gampang putih lan untune gampang entek). (BPL: 27) Jika diartikan ke dalam bahasa Indonesia yaitu idak boleh bangun tidur setelah matahari terbit, karena akan cepat tua dan rambutnya cepat beruban. 
Makna dalam data tersebut jika bangun tidur tidak boleh setelah matahari terbit, karena menurut orang Jawa jika orang tersebut masih muda maka usianya akan terlihat lebih tua dan rambutnya cepa beruban (MPL: 27).

\section{SIMPULAN}

Bentuk ungkapan pantang larang dalam komunitas adat Desa Karang Pandan Kecamatan Pakisaji. Temuan penelitian ini menunjukkan bahwa ungkapan pantang larang komunitas adat Karang Pandaan, Kecsamatan Pakisaji, Kabupaten Malang ini menggunakan bahasa Jawa. Dalam adat Jawa terdapat ungkapan pantang larang yang bermacam-macam. Mulai dari ibu hamil, suami yang mempunyai istri hamil, dalam kehidupan sehari-hari misalnya dalam bertata cara saat makan, tidur, berbicara dan lain sebagainya. Dari semua pantang larang yang dipaparkan dalam analisis data dan pembahasan tersebut, rata-rata semua itu tidak ada maksud lain kecuali agar semua orang hidupnya akan selamat dan tidak mengalami celaka. Tapi itu semua tergantung orang yang dinasehati tersebut, mau menanggapi ungkapan pantang larang tersebut dengan positif atau bahkan malah menyepelakan ungkapan tersebut yang dianggap tidak masuk akal. Karena sebagaian orang di zaman sekarang banyak yang tidak mempercayai ungkapan pantang larang tersebut, padahal kalau kita dalami masalah ungkapan pantang larang juga ada benarnya, karena sangat bermanfaat bagi kehidupan, agar kita juga mengetahui mana yang benar dan mana yang salah. Selain itu kita juga lebih bisa menjaga norma, adat, budaya, etika dan kesopanan dalam bermsyarakat.

Makna ungkapan pantang larang dalam komunitas Adat Desa Karang Pandan Kecamatan Pakisaji. Makna tersebut mejelaskan tentang bentuk ungkapan pantang larang yang diperoleh dari informan. Informan menjelaskan makna menggunakan bahasa Jawa yang ditafsirkan dan di analisis oleh peneliti menjadi bahasa Indonesia. Manfaat dari makna ungkapan pantang larang adalah memberikan pengetahuan terhadap komunitas adat dan peneliti tetntang adat, kebiasaan, norma dan aturan orang Jawa yang tidak sesuai dengan kaidah-kaidah yang berlaku di dalam masyarakat.

\section{SARAN}

Berdasarkan hasil penelitian yang telah dikemukakan pada bagian sebelumnya, berikut dikemukakan saran-saran yang ditujukan kepada komunitas adat Desa Karang Pandan, dan peneliti selanjutnya. Bagi Komunitas Adat Desa Karang Pandan, penelitian ini dijadikan sebagai bahan melestarikan dan mengembangkan kebudayaan serta norma yang berlaku di dalam masyarakat terutama bagi komunitas adat Desa Karang Pandan. Dapat mengajarkan ungkapan pantang larang ini kepada generasi penerus agar selalu menjaga norma, etika, dan kesopanan dalam kehidupan sehari-hari. Serta agar dalam hidup kita selamat, tidak mengalami celaka atau sesuatu hal yang tidak diinginkan. Bagi peneliti lanjut, dengan adanya temuan tentang penelitian ini, sangat terbuka peluang bagi kajian lanjut, terutama berkaitan dengan struktur dan fungsi ungkapan pantang larang. Dengan kajian-kajian lanjut tersebut diharapkan akan diperoleh temuan yang ebih lengkap tentang bentuk dan makna ungkapan pantang larang, guna untuk melestarikan dan mengembangkan sastra budaya, serta menjaga norma, etika dan kesopanan dalam kehidupan sehari-hari dalam komunitas adat di Desa Karang Pandan. 


\section{JURNAL ILMIAH BAHASA DAN SASTRA \\ Volume 4 Nomor 2 Tahun 2017 \\ eISSN : 25494155 - pISSN : 23557083}

\section{DAFTAR RUJUKAN}

Amir, Adriyetti. 2013. Sastra Lisan Indonesia. Yogyakarta: CV Andi Offset

Endraswara, Suwardi. 2005. Tradisi Lisan Jawa. Yogyakarta: Narasi $\begin{array}{llll}\text { (nurfatimahdaulay18.blogspot.com/?m=1diposkan } & 10 \quad \text { Januari }\end{array}$

MH, Yana. 2012. Falsafah dan Pandangan Hidup Orang Jawa. Yogyakarta: Bintang Cemerlang

Rafiek. 2012. Teori Sastra. Bandung: PT Refika Aditama

Sarmidi, Gatot. Keberadaan Wacana Pantang Larang Berlaras Gender Sebagai Tradisi Lisan Fenomena Bahasa dan Sastra di Indonesia. Makalah. Disampaikan dalam rangka Seminar Lokal Sastra Multi Disipliner FKIP Bahasa dan Sastra Indonesia Universitas Kanjuruhan Malang, 14 Januari 2014. 